\title{
The European Parliament in the post-crisis era: an institution empowered on paper only?
}

Citation for published version (APA):

Fromage, D. (2018). The European Parliament in the post-crisis era: an institution empowered on paper only? Journal of European Integration, 40(3), 281-294. https://doi.org/10.1080/07036337.2018.1450405

Document status and date:

Published: 01/01/2018

DOI:

10.1080/07036337.2018.1450405

\section{Please check the document version of this publication:}

- A submitted manuscript is the version of the article upon submission and before peer-review. There can be important differences between the submitted version and the official published version of record.

People interested in the research are advised to contact the author for the final version of the publication, or visit the DOI to the publisher's website.

- The final author version and the galley proof are versions of the publication after peer review.

- The final published version features the final layout of the paper including the volume, issue and page numbers.

Link to publication

\footnotetext{
General rights rights.

- You may freely distribute the URL identifying the publication in the public portal. please follow below link for the End User Agreement:

www.umlib.nl/taverne-license

Take down policy

If you believe that this document breaches copyright please contact us at:

repository@maastrichtuniversity.nl

providing details and we will investigate your claim.
}

Copyright and moral rights for the publications made accessible in the public portal are retained by the authors and/or other copyright owners and it is a condition of accessing publications that users recognise and abide by the legal requirements associated with these

- Users may download and print one copy of any publication from the public portal for the purpose of private study or research.

- You may not further distribute the material or use it for any profit-making activity or commercial gain

If the publication is distributed under the terms of Article $25 \mathrm{fa}$ of the Dutch Copyright Act, indicated by the "Taverne" license above, 


\section{The European Parliament in the post-crisis era: an institution empowered on paper only?}

\section{Diane Fromage}

To cite this article: Diane Fromage (2018) The European Parliament in the post-crisis era: an institution empowered on paper only?, Journal of European Integration, 40:3, 281-294, DOI: 10.1080/07036337.2018.1450405

To link to this article: https://doi.org/10.1080/07036337.2018.1450405
(2) 2018 The Author(s). Published by Informa UK Limited, trading as Taylor \& Francis Group

Published online: 31 May 2018.

\section{ש} Submit your article to this journal $\pi$

\section{Q View related articles $₫$}

View Crossmark data $\asymp$ 


\title{
The European Parliament in the post-crisis era: an institution empowered on paper only?
}

\author{
Diane Fromage \\ Law Faculty, Maastricht University, Maastricht, The Netherlands
}

\begin{abstract}
Following the adoption of Eurocrisis Law, the European Parliament (EP) has been strongly empowered in the Economic and Monetary Union. It may intervene mostly in three ways: by the means of control mechanisms around Euro summits, during Economic Dialogues and in the framework of the European Parliamentary Week and the Interparliamentary conference on Stability, Economic Coordination and Governance. An analysis of the practice reveals however that thus far this empowerment has remained largely theoretical; The EP could still better exploit the potential of its newly attributed capacities. The reform proposals currently under discussion were found to bear some potential if adequately used, despite being (still) of a soft nature like the ones currently existing.
\end{abstract}

\section{KEYWORDS}

European Parliament; Economic Dialogue; democratic legitimacy; SECG interparliamentary conference; Euro Summit

\section{Introduction}

On 6 December 2017, the European Commission presented its package for a reform of the Economic and Monetary Union (EMU). Over the past years the so-called Eurocrisis law generally considered to be composed of the European Union (EU) Six Pack and the (EU) Two Pack of legislation and of the (international) Treaty on Stability, Coordination and Governance (TSCG) and Treaty on the European Stability Mechanisms (ESM) - was adopted to safeguard the euro. All these norms were approved hastily at the peak of the economic and financial crisis between 2011 and 2013, and deeper reforms appear to still be necessary to strengthen EMU's resilience. While Eurocrisis law norms were approved with a varying level of participation of the European Parliament (EP) (Fasone 2014; Manoli and Maris 2015), they did grant it a more important role than it had previously (see on the EP's role in EMU before 2010: de la Parra 2015). The TSCG, in its article 13, foresees the establishment of an interparliamentary conference with the participation of national parliaments (NPs) and of the EP 'to discuss budgetary policies and other issues covered by this Treaty' (see also Griglio and Lupo 2018 in this issue). Article 12-5 TSCG additionally establishes the possibility for the EP's President to be 'invited to be heard' and ' $[\mathrm{t}] \mathrm{h}$ e President of the Euro Summit shall present a report to the European Parliament after each Euro Summit meeting'. On the other hand, the Six Pack 
and the Two Pack of legislation established what is known as the European Semester, which is a cycle of economic policy coordination divided into two periods of six months starting in November. At the beginning of each year, Member States fiscal and structural reforms are assessed by the Commission whereas the second half of each year is dedicated to the implementation of these decisions at national level. Although it is not the main institution involved, some prerogatives have been guaranteed to the EP in this framework: it is to enter in 'Economic Dialogues' both with EU institutions and with Member States 'to enhance the dialogue between the EU institutions on the application of economic governance rules and with Member States, if appropriate, to ensure greater transparency and accountability' (ECON Committee). The European Semester was additionally reformed in October 2015 to guarantee a better participation of the EP. The proposals made in December 2017 similarly entail some provisions on the EP's participation in the (reformed) EMU. For instance, they foresee the establishment of some accountability mechanisms between the EP and the new EU minister of finance. Thus, both considering the existing framework and considering the plans for its reform, important questions of throughput legitimacy arise. They are related to the exact scope and meaning of the EP's prerogatives, to the relations with the other institutions that are shaped on that basis as well as to the type of relations that are emerging between the EP and NPs.

Against this background, this contribution aims at analysing how the EP has made use of the new prerogatives it was conferred upon by Eurocrisis law. This will serve to determine whether such involvement of the EU legislature could contribute to greater transparency and accountability in the EU economic governance. The throughput perspective employed in this contribution therefore not only encompasses an empirical dimension, focusing on unravelling the relations between the EP and other EU institutions as well as with NPs. It also includes a normative dimension which enables evaluating the existing frameworks from the perspective of accountability and transparency (Schmidt 2012). Such a change would indeed be particularly welcome as the management of the Euro crisis was characterised, in its beginning at least, by an important lack of transparency and by the predominance of the European Council i.e. national executives. If compared to the EP and the Council, the Commission was much more strongly empowered following the adoption of Eurocrisis Law, though the European Council arguably also played a major role when the crisis was hitting hardest. Besides, in other policy areas that are key to the proper achievement of an EMU, such as tax law (art. 113 and art. 115 TFEU) or social law (art. 153 TFEU), the EP's participation is limited to being consulted so that it could be beneficial to compensate this partial involvement. The proposed analysis hence builds upon the existing literature on procedures such as the SECG Conference (Griglio and Lupo 2018 in this issue; Kreilinger 2013) or the European Semester analysed, for instance, in a recent special issue edited by Cooper, Maatsch, and Smith (2017). It adds to them by focusing exclusively on the EP, by building upon five years of practice and by assessing the latest reform proposals. Though it is undoubtable that the Member States will make changes to the Commission proposals, they still deserve attention as they will serve as a basis for discussion.

This article is structured as follows. It first examines the content and practice of the new prerogatives attributed to the EP following the latest reform of the EMU. Then the role it would receive under the proposed reform framework is examined to determine whether this would improve the EP's standing and hence enhance throughput legitimacy in EMU via the EP's participation in instruments such as the European Semester. Indeed, as the EP's 
contribution is circumscribed to the use of soft instruments, it cannot directly enforce citizens' preferences as expressed in their votes (input legitimacy). Rather, its involvement in the different procedures improves the openness and the accountability of the European executives, thereby improving throughput legitimacy of the EU's actions in this field. The role the EP played in the design of the current EU system of economic governance remains outside of the scope of this paper.

\section{Increased possibilities for the EP to participate in the post-crisis EU economic governance}

As part of its new and more numerous possibilities to be involved in the EU economic governance, mainly three avenues for the EP's participation exist: its activities around Euro Summits, its involvement in the Economic Dialogues and its (co-)organisation of European Parliamentary Weeks (EPWs) and of SECG Conference meetings.

\subsection{The relationship between the EP and the Euro Summit following the entry into force of the TSCG}

Although they were formalised by the TSCG, Euro Summits that bring together the heads of States and governments of the Member States part of the Eurozone (Eurozone Member States) have been existing longer. They date back to an initiative by former French President Sarkozy who launched them in October 2008. They were then organised on an irregular basis as the summit that followed this first initiative took place in May 2010. Three meetings were organised in 2011 when the crisis was hitting hardest however. With the approval of the TSCG a few months later (March 2012), the Euro Summit was formalised (art. 12). The frequency of the Euro Summits is not precisely set; they 'shall take place when necessary, and at least twice a year, to discuss questions relating to the specific responsibilities which the Contracting Parties whose currency is the euro share with regard to the single currency, other issues concerning the governance of the euro area and the rules that apply to it, and strategic orientations for the conduct of economic policies to increase convergence in the euro area'. In this framework, '[t]he President of the European Parliament may be invited to be heard [... and $t]$ ]he President of the Euro Summit shall present a report to the European Parliament after each Euro Summit meeting.' (art. 12-5). These procedures are similar to the ones established by article 235-2 Treaty on the Functioning of the European Union (TFEU) following which '[t] he President of the European Parliament may be invited to be heard by the European Council' and the European Council President normally presents a report in plenary session ex post, although this procedure does not create any direct accountability of the European Council towards the EP as it cannot ask any question (Wessels 2016, 90).

Consequently, the fact that economic issues are addressed in a European Council setting instead of being the object of Eurozone-specific Euro Summits does not necessarily result in a marginalisation of the EP since it is equally involved in the framework of European Council meetings. However, the formalisation of the previously informal Euro summits and the guarantee given to the EP that it may interact with the Euro Summit President should be assessed positively in that the EP does not depend on anyone's good will to be involved where Euro summits are preferred to European Council meetings. This notwithstanding, given the Eurozone-specific focus of Euro summits, the EP, which represents all EU citizens, is actually 
more legitimised to scrutinise the European Council than it is to control Euro summits. After the entry into force of the TSCG, and with the exception of the crisis that surrounded the third Greek bail-out in July 2015, Euro Summits had originally not been organised frequently: only one in 2013, one in 2014 and three in 2015 around the Greek 'problem'. No meeting was convened in 2016, and they were only resumed in December 2017. The absence of such meetings for two years may be due to the fact that the economic questions that needed discussing were linked to the daily management of the Eurozone, affected all EU Member States and were hence addressed in the framework of the European Council. In fact, the European Council does hold two debates in the framework of the European Semester every year - in March and in June. Additionally, Eurogroup meetings that bring together ministers of the Eurozone Member States take place on a monthly basis so that perhaps Euro Summits were less necessary. By contrast, Euro summits are required now that important changes to the EMU's architecture are envisaged, and two meetings are already scheduled for the first half of 2018.

As concerns the EP's involvement so far, in the statements published after the three latest Euro Summit (7 and 12 July 2015, 15 December 2017) no reference was made to any invitation of the EP President, while the Presidents of the ECB, the Eurogroup and the Managing director of the IMF were invited to the 22 June 2015 meeting (Tusk 2015). Hence, the possibility for the EP to participate in this forum has thus far remained virtual. While this is unsurprising of the Euro summits that took place during the extreme situation of the Greek bail-out of July 2015, it is rather unexpected of the December 2017 summit that addressed key issues for the future of EMU. This lack of involvement is arguably (partially) compensated by the fact that the President of the EP commonly participates in the European Council meetings since the entry into force of the Lisbon Treaty, even if no obligation exists in this sense: Article 235-2 TFEU simply states that the President may be invited. His participation is nevertheless limited to an opening speech after which he must leave. The deficit in the EP's involvement that existed in the framework of the negotiations with Greece in July 2015 was in fact criticised during the debate in plenary organised on 8 July 2015. If the EP is not involved either in the Euro summit scheduled in March 2018, during which the future of EMU will be further addressed, a similar reaction may be expected: even if, like in December 2017, Euro summits take place at the same time as European Council meetings in whose framework the EP President is involved indeed, a debate of 30 min shared with another speaker as in December 2017 can certainly not be considered as sufficient to ensure adequate (throughput) legitimacy.

As regards ex post reporting duties, before the TSCG entered into force, the European Council President had not reported on Euro Summits in two occasions - May 2010 and July 2011 - but at that time no formal obligation in this sense existed. Later on, it did so though he reported jointly on the Euro Summit and on the European Council meeting which are commonly taking place one after the other (this had not happened in the occasion of the May 2010 and July 2011 meetings). The importance of the decisions taken at the time justifies the analysis of the fulfilment of the reporting duties after European Council meetings when the future of the Eurozone (2010-2013 mostly) was at stake. Between 2010 and 2015, the President of the European Council did fulfil his obligations in a majority of cases, although he submitted his report on the December 2013 European Council meeting in writing and he could not appear in March 2014 (all data extracted from: Vanden Broucke, Poptcheva, and de Finance 2014, 6f). After'special' and 'extraordinary' meetings former European Council 
President Van Rompuy did not systematically report, and he did not report after informal meetings either as 'he could not'report any formal conclusions ... from an informal meeting', adding that those informal European Councils were only aimed at preparing future deliberations' (Vanden Broucke, Poptcheva, and de Finance 2014, 6). A similar attitude could be observed after Brexit was triggered and the Heads of States decided to meet without their UK counterpart (this happened for instance in September and in December 2016). No reporting was done after the February 2017 informal meeting on migration either.

In sum, the TSCG added an additional layer of accountability and participatory rights to the decisions taken in the framework of the Euro Summit. Yet, thus far, these two new possibilities have not been extensively used because there have been very few Euro Summits. When they did take place however the President of the EP was not invited to participate contrary to what has become the rule for European Council meetings. In this sense, this systematic participation in European Council meetings, which have been far more frequent, can be said to have guaranteed a more adequate participation of the European legislature. In the current context of reform, it is however key that the EP is sufficiently and specifically involved.

By contrast, ex post reporting duties have been less perfectly observed. Since the entry into force of the Lisbon Treaty, the European Council President has arguably reported to the European Parliament after Euro Summits. And so he did after European Council meetings. But reports are not systematically made to the EP after'non-ordinary' meetings despite their importance as it was the case of the post-Brexit EU-27 meeting. Despite formal guarantees, the EP does not (yet) represent a fully functioning channel for enhanced transparency and accountability.

\subsection{Another new instrument: the Economic Dialogues}

Following the EP's request for more democratic surveillance and more participation during the negotiations of the Six Pack rules (Fasone 2014, 171; Manoli and Maris 2015, 82), when the annual European Semester was formalised, the possibility for the EP to enter in an 'Economic Dialogue' both with EU institutions and with Member States was established to discuss the various coordination and surveillance measures. Each of the pieces of legislation contained in the Six Pack - except for the Directive - and the Two Pack of legislation foresees the possibility for an Economic Dialogue with the other EU institutions on the one hand, and with Member States on the other.

As concerns the Dialogue with EU institutions, the EP may invite the President of the Council, the Commission and, where appropriate, the President of the European Council or the President of the Eurogroup to appear before its competent committee to discuss matters related to the surveillance of budgetary positions and the surveillance and coordination of economic policies (Article 2-ab Regulation No 1175/2011). Decisions taken on the basis of articles 126-6 and 126-11 TFEU (i.e. whether an excessive deficit exists and whether certain measures should be taken where a Member State'persists in failing to put into practice the recommendations of the Council' (art. 126-9 TFEU)), on Council recommendations on the basis of article 126-7 (i.e. recommendations in order for a Member State to cease being in excessive deficit), and on Council notices on the basis of article 126-9 TFEU (i.e. notices containing Council recommendations for deficit reduction where a Member State has not put in practice the recommendations of the Council) may also be the object of Dialogues 
(Section 1A Regulation No 1177/2011). In addition, in the framework of the mechanisms contained in these two Regulations, the Council is expected to, as a rule, follow the recommendations and proposals of the Commission or explain its position publicly, i.e. potentially to the EP in the framework of the Dialogues as this condition is contained under the title of the different Regulations and Directives that addresses the Economic Dialogue.

These avenues open to the EP to initiate dialogues are complemented by its possibility to invite the same European institutions representatives to discuss decisions taken in the framework of the preventive arm of the Stability and Growth Pact (SGP), i.e. interest-bearing deposits, non-interest-bearing deposits and fines (art. 3 Regulation 1173/2011 on the effective enforcement of budgetary surveillance in the euro area). Other topics of Dialogues are the multilateral economic surveillance in the pursuant of the prevention and correction of macroeconomic imbalances (Article 14 Regulation 1176/2011) as well as sanctions including fines to correct excessive macroeconomic imbalances (article 6 Regulation 1174/2011).

In addition to these possibilities contained in Six Pack norms, other possibilities exist with regard to Eurozone Member States as foreseen in Two Pack norms to discuss matters related to the monitoring and the assessment of draft budgetary plans (article 15 Regulation 473/2013 - where also the EP's involvement in the European Semester to 'increase the transparency and ownership of, and the accountability for the decisions taken' is emphasised) and to the economic and budgetary surveillance of Member States experiencing or threatened with serious difficulties with respect to their financial stability (article 18 Regulation 472/2013; this Dialogue is only limited to the Council and the Commission though).

The level of detail of these provisions is remarkable as it opens large possibilities for the EP to organise hearings, but these debates are to take place before the'relevant committee', not in plenary. In fact, the EP requested in 2015 that the overall assessment on common provisions for monitoring and assessing draft budgetary plans and ensuring the correction of excessive deficit of the Member States in the euro area be submitted to a debate in plenary instead (European Parliament 2015). This would make sense, particularly because the EP's possibilities of influence are limited to this soft instrument, i.e. hearings, and hearings in plenary entail far more power, peer pressure and visibility vis-à-vis the larger public than hearings in committee. This would also contribute to bring these issues to the fore instead of them being exclusively dealt with by a reduced number of specialised MEPs. Some pressure is arguably set in parallel on the Council for it not to seek to reduce the Commission's powers since it is bond by the 'comply or explain' principle and will have to justify publicly any case of deviation from the Commission's position as underlined above. This in turn would give ground for the EP to hold the Council to account by asking it to appear for a hearing; the Commission has also increasingly seized this possibility to enforce its position (Coman and Ponjaert 2016,47). What would happen (beyond political consequences) if the Council were to refuse to accept the EP's invitation is however unclear. In any case, the general rules on accountability contained in article 17-8TEU and in the Framework Agreement on relations between the EP and the Commission apply as well.

In addition to these procedures of dialogue with other EU institutions, the EP can enter an Economic dialogue with Member States in the framework of the same procedures designed by the Six Pack: SGP, Macroeconomic Imbalance Procedure (MIP), Enhanced surveillance or macroeconomic adjustment programmes (Eurozone Member States) and Enhanced monitoring of national budgetary plans (Eurozone Member States). The EP may additionally invite Member States for an exchange of views regardless of the existence of 
any specific legal basis so that the possibilities of exchanges are extremely numerous and comprehensive. Member States are however not obliged to accept these invitations. Given the limited role of the EP itself in the European Semester procedures, the predominant positive aspect of such an exchange of views will be political. Such a Dialogue will therefore be attractive for the invited Member State only if it assured of the support it will receive.

Three years of Economic Dialogues allow the drawing of some (preliminary) conclusions as to their potential in practice. The Dialogue with other EU institutions will be examined first, and then the Dialogue with Member States will be considered.

As it stood when it was launched in 2011, the European Semester foresaw three different periods of Economic dialogues with the EP: in January-February on the Annual Growth Survey, in March on the European Council and the Annual Growth Survey, and on Country Specific Recommendations in July. This schedule was reformed in 2015 through the Five Presidents' report: The first of these debates now takes place in November-December whereas the second now addresses the draft Country Specific Recommendations and takes place in May and June. A debate followed by the adoption of a resolution on the European Semester and the Country Specific Recommendations is organised in September, whereas the dialogue on the Annual Growth Survey starts in October. Thanks to these changes, the EP is not confronted with a fait accompli anymore but it can try and influence Country Specific Recommendations for instance. These changes should be praised because there is little sense in the EP being involved if decisions have already been made.

The Five Presidents report also raised additional ideas to enhance the added-value of parliamentary participation. In particular, the possibility for the European Commission to engage with the EP during a plenary debate before the Annual Growth Survey is published and after it is adopted was envisaged (European Commission 2015, 17). Another plenary debate could be organised after the European Commission has presented its Country Specific Recommendations. Changes were put in practice soon after the adoption of the report and the EP's relationship to the Commission intensified in 2016 and 2017 (European Parliament 2017a). For instance, the Annual Growth Surveys for 2016 and 2017 were debated in plenary ahead of their adoption and the Euro area recommendations proposed by the Commission were the object of an exchange of views in plenary with the Commission and the Eurogroup Presidents.

The Economic Dialogues with other EU institutions have been taking place on a regular basis since 2014 (European Parliament 2017b). They have mostly involved Member States representatives, although Commissioners were regularly heard too. The President of the ECOFIN Council participated in 11 occasions between January 2014 and March 2017, the President of the Eurogroup in seven, whereas commissioners were heard 11 times over the same period. It is worth noting that while a large majority of these exchanges took place as part of the ordinary functioning of the European Semester or as 'regular economic dialogues', others concerned specific topical issues. For instance, in October 2016, two commissioners were heard on the suspension of European Structural and Investment Funds. It results that despite the absence of remedy in case of refusal to participate to these exchanges, the other EU institutions have been largely ready to take part in these procedures which, in turn, has contributed to their increased visibility and transparency.

For what concerns Dialogues with Member States, 15 of them have engaged in an Economic Dialogue with the EP in 15 meetings since 2012 (European Parliament 2017c). These differences among Member States may be explained by the fact that not all of them 
have been in any of the circumstances foreseen by the Six Pack and the Two Pack. As noted above, an exchange of views could still have been organised regardless - and five were - but there are also some cases in which an Economic Dialogue would be possible but the EP has not taken any initiative in this sense as of yet. Regardless, the organisation of 20 meetings in four years showcases the EP's willingness to become an active player in the European Semester procedures, even if it itself has only a marginal influence on the process.

The EP was hence successful in introducing the Economic Dialogues during the negotiations of the Six Pack and, as shown, these mechanisms have been fairly used in practice. Nevertheless, the EP's role should not be overestimated as it is confined to the control of the results of surveillance mechanisms and the correct application of legislation: no reporting mechanisms exist (Manoli and Maris 2015, 82). Also, only the Commission and the President of the Council are legally obliged to inform the EP; no such obligation rests on the President of the European Council and on the President of the Eurogroup who do have to appear before the competent committee but are under no obligation to inform the EP about their activities except when they concern the results of multilateral surveillance; consequently, the EP cannot hold them to account adequately (Repasi 2016, 45)

\subsection{EPW and SECG interparliamentary conference as additional means of influence for the EP}

A third instrument for the EP's participation in EMU is the SECG Conference which brings together members of the EP and of NPs on a bi-annual basis. Its setting up was particularly lengthy and difficult as disagreements existed as to, among others, the scope of action of the Conference or the size of the delegations (Cooper 2014). In this context, conflicting views appear to have existed between, on the one hand, (some) NPs and the EP and on the other hand among NPs. This may not come as a surprise given the weak institutional position the EP holds in this policy area (Maurer 2013, 5), and given the delicacy of the matter for NPs who see one of their main prerogatives - budgetary powers - being strongly affected by a novel and important empowerment of the European Commission through Eurocrisis law.

Another crucial point for the definition of the EP's position was the determination of the legal basis on which this Conference had to be based. Although the SECG Conference is developed within the EU and brings together all EU NPs, its legal basis lies in Article 13 TSCG rather than in Article 12 TEU and in Protocol 1 appended to the Treaties like it is the case for the other interparliamentary conferences. This notwithstanding, article 13 TSCG clearly refers to the European Treaties - Title II Protocol 1 - and article 9 of this same Protocol was used to establish this new interparliamentary conference. As a result of this choice COSAC was completely marginalized; had article 10 been resorted to instead, COSAC would at least have had a coordinating role and this would have implied that the EP's and NPs' delegations are of the same size. The decision to resort to article 9 instead of article 10 hence played to the advantage of the EP since it can send as large a delegation as it wishes and it can play a prominent role. The EP was additionally successful in obtaining co-chairing responsibilities between the presidency parliament and the EP for the meeting taking place during the first half of the year. It may hence play a greater role in the definition of the agenda and that contributes to blur the distinction between SECG Conference and EPW/European Semester Conference. The impossibility for the EP and NPs to come to an agreement on the issue of the size of the delegations could result in a more limited capacity of the Conference to 
contribute to enhanced accountability in EMU. As a fairly unstable forum with a largely varying participation of parliaments as illustrated below and with members stemming both from Euro area and non-Euro area Member States, it could prove difficult for the Conference to establish itself as a strong forum for more accountability in EMU. The fact that it does not possess any standing secretariat and cannot resort to COSAC's secretariat also plays against its strengthening (see also Griglio and Lupo 2018 in this issue on these points).

Next to the SECG Conference, the EP also organises an informal EPW every year in February. This initiative dates back to 2011 when the EP's Committee on Economic and Monetary Affairs (ECON Committee) organised a meeting with national Members of Parliament (MPs) to 'discuss their first experiences with the 'European Semester" (European Parliament 2016, 7). A similar initiative existed in 2012 and this event was finally renamed EPW in 2013. It has since been organised at the beginning of each year, alongside the SECG Conference meeting. It appears though that this first yearly meeting of the SECG annual Conference has become fully integrated in the EPW; the EP deems the EPW to be composed of the 'European Semester Conference' and the SECG Conference meeting. In fact, the EP's website devoted to its relations with NPs does not mention the SECG Conference under the heading 'Conferences'. It only refers to the EU Speakers' Conference, COSAC, Common Foreign and Security Policy Conference and the EPW. Hence the autumn meeting of the SECG Conference is not considered. This fact combined to the initial reluctance of the EP to positively participate in the creation of the new interparliamentary conference may indicate that the European legislature seeks to keep a predominant position in this field of interparliamentary cooperation.

It is unlikely that the SECG Conference will contribute to any enhancement of democracy within EMU that would take any form going beyond the exchange of information and best practices among MPs and MEPs (Chopin 2016, 7f; Fromage 2016). This is due to the absence of agreement regarding the size of the delegations and to the varying attendance of MPs with several Member States not being represented or being represented only by administrators in several occasions. As a result, whereas the EPW/SECG Conference meetings organised in Brussels are characterised by a very strong participation of MEPs - 60 MEPs vs a total of 140 MPs in 2014; 70 MEPs vs. 110 MPs in 2015; 45 MEPs vs. 130 MPs in 2016 - this difference in terms of representation is much less salient in the meeting organised during the second half of each year (14 in 2014; 12 in 2015; 12 in 2016), and it appears to be diminishing too. The average per national delegation has varied between 2 and 4 . A determining factor in the EP's wide participation may be related to its large, in particular financial, resources which allows it to send a large delegation without any further difficulty. Its weak institutional position if compared to its now most common role as co-legislator may be an incentive for it to be largely represented to compensate for this otherwise perhaps somewhat unsatisfactory and frustrating situation. One additional sign of the marginalisation of the SECG Conference and the lack of attention it receives from the EU institutions in general can be derived from the fact that the Five Presidents' report of 2015 does not even mention it despite its intrinsic link with the report's objective of 'Completing Europe's Economic and Monetary Union'. Yet, it does make extensive references to the EPW indeed (European Commission 2015, 17) thereby contributing again to the reinforcement of the EP's position, perhaps in an attempt to compensate for the otherwise rather marginal role attributed to it in the framework of the European Semester.

The EP is also seeking to expand its cooperation with NPs in this domain via the organisation of 'ordinary' meetings at committee level. The ECON Committee organises yearly 
meetings in September to exchange on its draft report on the European Semester with its national counterpart.

Overall, the large number of MEPs who assist to these meetings points to a large interest of the EP. Given the other possibilities of influence - or at least of accountability - the EP has at its disposal as shown above, interparliamentary cooperation could also be in NPs' interest and could contribute to enhancing democratic legitimacy in this area. Indeed, through the exchange of information with NPs the EP may be better placed to hold the Commission to account in the framework of the Economic Dialogues and in the framework of the hearings it may organise following European Council meetings and Euro Summits. In other words, interparliamentary cooperation represents an avenue for the EP (and NPs) to reduce their informational asymmetry (Curtin 2013) vis-à-vis the EU (and the national) executives. Of course, NPs remain the primary actor in charge of holding national executives to account in any case. These interparliamentary meetings offer a further opportunity for the EP (and for NPs) to have a direct exchange with the President of the European Commission and with the Commissioner for Economic and Financial Affairs, Economics and Taxation. Whether a dialogue can be truly established remains to be seen as schedules are usually tight and sometimes no time is reserved for questions. But at least the opportunity may be created. The will was actually expressed in the Five Presidents' Report to have Commission and Council representatives participate in the EPW (European Commission 2015, 17) and this report even launched the idea of a non-binding interinstitutional agreement in this sense between the Commission, the ECOFIN Council, the Eurogroup and the EP (European Commission 2015, 17); this idea was raised again by Commission President Juncker when he addressed MEPs and MPs during the EPW 2016 but it has thus far not borne any fruit.

In the absence of such an interinstitutional agreement, the EP could seek to make exchanges more fruitful in avoiding overlaps between its European Semester Conferences and the SECG Conference meetings and in making the EPW'more purposeful' as suggested by the British House of Lords (House of Lords 2016, par. 186). The SECG Conference could also be given 'more substance' (European Parliament 2017d, point 1).

\subsection{The enhanced yet still weak position of the EP}

Following the adoption of Eurocrisis Law, the EP is thus in a better position than it was before: it now has the possibility to call for the organisation of hearings and exchanges of views to be better informed and to play a predominant role in forums for interparliamentary cooperation. All these instruments are however rather soft in their nature: the EP is not formally deciding on anything and it is not able to truly balance the Commission's extended powers. Rather it may only bring to the fore debates on decisions in the economic and fiscal domain which would otherwise be taking place in a more discrete fashion or only within Member States. Practice shows that the instruments that do exist are being used but they would need to be enhanced to ensure more transparency and accountability.

\section{Reform prospects}

Now that the EU appears to be recovering, (certain) Member States and the European Commission are inclined to push for the further strengthening of EMU to correct existing 
flaws. It is with this aim that the Commission published several guiding documents, and most notably its Roadmap for deepening Europe's EMU, in 2017.

In its Reflection paper on the deepening of the EMU, the Commission for instance expressed the idea that the Economic Dialogue could be formalised before the end of 2018 (European Commission 2017a, 28-29). It also envisaged an agreement on the democratic accountability of the euro area which should be approved before the 2019 EP elections and later integrated in the EU Treaties (European Commission 2017a, 29).

The Roadmap recently published (European Commission 2017c) builds up on the Reflection paper and entails four main proposals: The establishment of a European Monetary Fund (EMF), the integration of the substance of the intergovernmental TSCG in EU law, the introduction of new budgetary instruments for a stable euro area within the Union framework and the creation of a European Minister of Economy and Finance. Additionally, the Commission defines three main priorities: Unity, efficiency and democratic accountability, with the latter being particularly relevant for the EP's future role in EMU. Despite this apparent emphasis on accountability, a careful examination of the Commission's proposals points to a (perhaps) disappointing result both for the EP, and even more so, for NPs.

The creation of the EMF, i.e. the incorporation of the intergovernmental ESM in EU law, specifically aims at fostering its

institutional anchoring [...] to create new synergies within the EU framework, notably in terms of transparency, legal review and efficiency of the EU's financial resources [... Most importantly in the context of the current analysis,] it will also help improve further the cooperation with the Commission and the accountability to the European Parliament. (European Commission 2017c, 4)

To this end, several provisions have been included that closely resemble those existing in the framework of the Banking Union (see Fromage and Ibrido 2018). The EP should receive the EMF's annual report, respond to oral and written questions and the EMF's managing director can be heard by the EP on either institution's request. He or She should also be appointed upon consultation of the EP. All of these possibilities of action open to the EP would clearly enhance its position as it currently has no capacity at all to intervene in the ESM. But these instruments are rather weak, and their main potential lies in the possibility they offer to enhance transparency and public accountability on the EMF's decisions. Since the Council regulation proposal made by the Commission is based on the flexibility clause (art. 352 TFEU), which requires the EP's consent, it can be expected that the European legislature will however try to further empower itself like it did when the Six Pack measures were adopted.

Regarding the inclusion of the substance of the TSCG in EU law, it is particularly noteworthy that the Commission refers to the SECG conference as'the inter-parliamentary meetings held annually by the European Parliament' in its Roadmap (European Commission 2017c, 8) thereby bluntly neglecting NPs' importance and co-chairing responsibilities. Such a position is coherent with previous Commission statements emphasizing the EP's sole responsibility as the Parliament of the EU (European Commission 2012) and with its plea for unity within the EU, and it can be expected to be welcomed by the EP. Contrary to the Roadmap, the specific Commission proposal more neutrally states that 'Article 13 of the TSCG lays down that budgetary policies and other issues covered by that Treaty will be discussed in the framework of inter-parliamentary meetings held by the European Parliament and the national Parliaments of the Contracting Parties [...]. This Directive should apply without 
prejudice to that practice, since such dialogue contributes to enhancing democratic accountability in the context of the Union's economic governance' (Recital 17, Directive proposal COM (2017) 824 final). Here it appears that the Commission simply wishes for the existing practice to be pursued. In any event, given the existing shortcomings evidenced above, even a formal endorsement of the EP's role in this framework by the Commission could not be expected to effectively contribute to better transparency and accountability. Furthermore, the EP's capacity to enhance its role during the negotiation process is more limited than in the case of the EMF presented above as it must only be consulted as per the legal basis chosen (art. 126(14)(2) TFEU). It is thus unlikely that it will succeed in obtaining significantly more far-reaching prerogatives.

Finally, the creation of a European Minister of Economy and Finance could also bear some limited consequences on the EP's standing in EMU. In the introduction to its Communication, the Commission claims that'the Minister would [...] contribute to strengthening the transparency of EU policy-making [and] accountability towards the European Parliament' (European Commission 2017b, 1). This new figure would in fact be a Vice-President of the Commission and he/she would simultaneously become the President of the Eurogroup, who also currently chairs the Board of Governors of the ESM. As Commission members are accountable to the EP, the European legislature would gain accountability rights it currently lacks over the ESM/EFM and the Eurogroup. These provisions, combined with the EP's foreseen consultation during the appointment procedure of the EFM's managing director, would provide it with comprehensive instruments to enhance the transparency and the accountability of the EFM's management and decision-making procedure. It would also open complementary avenues of enhanced accountability of Eurozone-specific bodies: not only would the EP be somehow involved in the framework of Euro Summits but it could also ask questions and request information of the Eurogroup. The question can however be asked whether such multiplication of portfolios in the figure of the Minister (i.e. Commissioner, Eurogroup Chair and EFM Board of governors Chair) will not in practice render accountability more difficult to ensure for MEPs as it may not be always easy to identify in whose framework they should interrogate the Minister on its different functions. It is in any case hard to believe that the Member States will support the Commission proposal as it currently stands by accepting that a commissioner, instead of a national minister, endorses the role of European Minister; Hence, the issues previously identified are rather remote and the EP's standing will have to be assessed anew at a later stage of the discussions.

\section{Concluding remarks: true empowerment or not?}

Undoubtedly, the EP is better-off in the EMU than it was before the adoption of Eurocrisis law. It did indeed manage to gain some rights and prerogatives, though its position could still be improved. Additionally, it was largely ignored in mechanisms in whose adoption it did not act as a co-legislator such as the TSCG or the ESM Treaty, though it had an influence on the TSCG's content (Fasone 2014, 172-173).

This weakness is certainly due in part to the existing duality between Eurozone and non-Eurozone Member States since the EP itself represents the European citizens in their entirety and it is called to play a role in domains in which the intergovernmental instances only bring Eurozone representatives together. This weakness of the EP could explain why it is reluctant to wholeheartedly participate in the SEGC interparliamentary conference and 
(partly) why this initiative has consequently failed to develop so far as an effective forum for interparliamentary cooperation.

Economic Dialogues may be convened in very numerous circumstances and a further analysis of their content is required to draw final conclusions as important shortcomings exist: they only offer the possibility for an ex post control and the duty to transmit information is limited to some institutions and bodies only. Yet, they have been regularly organised and in that sense, have, at least partially, improved the EP's position.

Contrary to the Economic Dialogue, the specific Euro Summit procedure established by the TSCG was originally barely used and where they did indeed take place, the EP was not involved adequately. Given the important stake of the current reform proposals, this should however, and will hopefully, be changed in the future.

It thus appears that the newly introduced mechanisms for the EP's involvement in EMU still entail some potential the EP could exploit. The reforms recently proposed by the Commission could contribute to the further enhancement of the EP's role as it would no longer be fully an outsider to the EMF and the potential of the Minister of Finance as a Commission Vice-President has been emphasized. The proposed changes do not clearly depart from the current state-of-play in that they do not provide the EP with any 'strong' power; whether this should have been otherwise remains outside of the scope of the present analysis. In any case, if both the existing and the new instruments were adequately used, the EP could enhance EMU's throughput legitimacy in, for instance, fostering the openness of the decisions made within the framework of the EMF and in increasing the EU executives' (Commission and Euro Summits) accountability records. This would already represent an improvement of the current state of play.

\section{Disclosure statement}

No potential conflict of interest was reported by the author.

\section{Funding}

This work was supported by Spanish Ministry of Economy and Competitiveness [grant number DER2014-57116P].

\section{References}

Chopin, T. 2016. "Zone euro, légitimité et démocratie: comment répondre au problème démocratique européen?" Question d'Europe no 387, Fondation Robert Schuman.

Coman, R., and F. Ponjaert. 2016. “From one Semester to the Next: Towards the Hybridization of New Modes of Governance in EU Policy." Cahiers du CEVIPOL Brussels Working Paper issue on the EU economic governance 5/2016, 32-57.

Cooper, I. 2014. "Parliamentary Oversight of the EU After the Crisis: On the Creation of the 'Article 13' Interparliamentary Conference." LUISS School of Government Working Papers SOG-WP21/2014.

Cooper, I., A. Maatsch, and J. Smith. 2017. Special Section "Analysing the Role of Parliaments in the European Economic Governance". Parliamentary Affairs 70 (4): 645-739.

Curtin, D. 2013. "Challenging Executive Dominance in European Democracy." Amsterdam Law School Legal Studies Research Paper No. 2013-2077.

ECON Committee, European Parliament. "Economic Dialogues." http://www.europarl.europa.eu/ committees/en/econ/econ-policies.html?tab=Economic\%20Dialogues. 
European Commission. 2012. Communication A Blueprint for a Deep and Genuine Economic and Monetary Union Launching a European Debate. COM(2012) 777 final/2.

European Commission. 2015. “Five Presidents Report. Completing Europe's Economic and Monetary Union".

European Commission. 2017a. Reflection Paper on the Deepening of the Economic and Monetary Union.

European Commission. 2017b. Communication A European Minister of Economy and Finance. COM(2017) 823 final.

European Commission. 2017c. Communication On Further Steps Towards Completing Europe's Economic and Monetary Union: A Roadmap. COM(2017) 821 final.

European Parliament. 2015. Report on the Review of the Economic Governance Framework: Stocktaking and Challenges. (2014/2145(INI)).

European Parliament. 2016. Relations Between the European Parliament and National Parliaments under the Treaty of Lisbon. Annual Report 2014-2015.

European Parliament. 2017a. Legislative Train Schedule. Deeper and Fairer Economic and Monetary Union. European Semester Improvement. http://www.europarl.europa.eu/legislative-train/theme-deeperand-fairer-economic-and-monetary-union/file-european-semester-improvement.

European Parliament. 2017b. Briefing "Economic Dialogue with the other EU Institutions under the European Semester Cycle." State of Play, March 2017.

European Parliament. 2017c. Briefing "Economic Dialogue and Exchanges of Views with Member States under the European Semester Cycles." State of Play, March 2017.

European Parliament. 2017d. Resolution on Budgetary Capacity for the Euro Are. 2015/2344(INI).

Fasone, C. 2014. "European Economic Governance and Parliamentary Representation. What Place for the European Parliament?" European Law Journal 20 (2): 164-185. doi:10.1111/eulj.12069.

Fromage, D. 2016. "European Economic Governance and Parliamentary Involvement: Some Shortcomings of the Article 13 Conference and a Solution." Cahiers européens de Sciences Po.

Fromage, D., and R. Ibrido. 2018. "The 'Banking Dialogue' As a Model to Improve Parliamentary Involvement in the Monetary Dialogue?" Journal of European Integration.

Griglio, E., and N. Lupo. 2018. "The Conference on Stability, Economic Coordination and Governance: Filling the Gaps of Parliamentary Oversight in the EU." Journal of European Integration.

House of Lords. 2016. "'Whatever it takes': The Five Presidents' Report on Completing Economic and Monetary Union." European Union Committee 13th report of session 2015-2016, HL Paper 143.

Kreilinger, V. 2013. "La nouvelle conférence interparlementaire pour la gouvernance économique et monétaire." Notre Europe Policy paper 100.

Manoli, P., and G. Maris. 2015. "The Role of the European Parliament in Managing the International Economic Crisis." In The European Parliament and its international relations, edited by Stelios Stavridis and Daniela Irrera, 70-91. Abingdon: Routledge.

Maurer, A. 2013. "From EMU to DEMU: The Democratic Legitimacy of the EU and the European Parliament." IAI Working papers 13/11.

de la Parra, S. 2015. "La légitimité démocratique de I'Union économique et monétaire." In L'Union économique et monétaire: origine, fonctionnement et futur, edited by Frédéric Allemand. Luxembourg: Sanem, Centre Virtuel de la Connaissance sur l'Europe. http://www.cvce.eu/education/unitcontent/-/unit/7124614a-42f3-4ced-add8-a5fb3428f21c/7e60f711-c3e5-4491-a4de-d862a47e4333.

Repasi, R. 2016. European Parliament Study for DG for Internal Policies on "Implementation of the Lisbon Treaty. Improving Functioning of the EU: Economic and Monetary Policy".

Schmidt, V. 2012. "Democracy and Legitimacy in the European Union Revisited: Input, Output and 'Throughput".' Political Studies 61 (1): 2-22. doi:10.1111/j.1467-9248.2012.00962.x.

Tusk, D. 2015. "Invitation letter to the Euro Summit, 19 June 2015".

Vanden Broucke, J. R., E.-M. Poptcheva, and S. de Finance. 2014. "The European Council and its President." EPRS Briefing.

Wessels, W. 2016. The European Council. London: Palgrave. 